\title{
TREES AS ECOSYSTEM ENGINEERS DRIVING VEGETATIONAL RESTORATION/RETROGRADATION OF INDUSTRIAL DEPOSITS IN CULTURAL LANDSCAPE
}

\author{
Prausová Romana ${ }^{1}$, ŠTEFÁNEK Michal ${ }^{1,2}$, RAUCH OTA $^{2}$, KOVÁR̆ PAVEL $^{2 *}$ \\ ${ }^{I}$ Department of Biology, Faculty of Science, University of Hradec Králové, \\ Rokitanského 62, 50003 Hradec Králové \\ ${ }^{2}$ Department of Botany, Faculty of Science, Charles University in Prague, Benátská 2, \\ 12801 Praha 2, *Corresponding author,e-mail: pavel.kovar@natur.cuni.cz.
}

Received: $31^{\text {th }}$ July 2017, Accepted: $2^{\text {nd }}$ August 2017

\begin{abstract}
Industrial processes are marked with various deposits of wastes in landscapes. They are typically characterized by high pollution levels in all their ecosystem components, including soil, water and air. Even more than natural ecosystems, artificial ash and mine tailings containments or industrial dumps are disconnected from nature or agricultural surroundings by their construction geometry. This combination of factors directs such patches of landscape to the isolation (island) effect and hihglighting of land-surface fragmentation. What is the most proper tool serving efficiently for support of sharp boundaries dissolution and comeback of the habitat close to natural one? In the European climatic conditions, trees function as reliable ecosystem engineers under the conditions of keeping sites without human interventions. However, spontaneous colonization and succession include vegetational phases of both increased species diversity (advanced successional stages) and secondary species diversity reduction (successional retrogradation), usually in dependence on the soil-substrate development.
\end{abstract}

Keywords: trees, industral deposits, landscape, abandoned sedimentation basin, tailings containment, ore-washery, primary succession, vegetation restoration, retrogradation, toxic substrate, ecosystem engineers

\section{INTRODUCTION}

Ecosystem engineers affect other organisms by creating, modifying, maintaining or destroying habitats (Byers et al., 2006). All the mentioned functions can establish conceptual framework that shows how consideration of ecosystem engineers can be used for assessment of processes involved to natural restoration of damaged or quite new ecotopes. Distinguishing features of ecosystem engineers are that they affect the physical space in which other species live and their direct effects can last longer than the lifetime of the organism (Hastings et al., 2007). Organisms that mainly govern directions of the artificial ecosystem life come across similar stages of ecological succession (Prach et al., 2016). Greening of raw soils, toxic industrial deposits and N-poor substrates in temperate regions are covered by woodland in relatively short time if propagules are available (e.g., Rebele et 
Lehmann, 2016). The application of indigenous plant species with mycorhiza is an excellent eco-engineering measure to initiate and accelerate the re-colonisation and stabilization of soils and raw materials deposited in landscapes (Graf et Frei, 2013). In general, woody plant species can be considered physical ecosystem engineers since they modify their environment by creating patches that differ in their ecosystem properties from unengineered patches (Paz-Kagan et al., 2016).

\section{TRAJECTORY OF REVEGETATION - OVERVIEW OF LONG TERM CASE STUDY IN ABANDONED TAILINGS CONTAINMENT FROM MANGANESE-ORE MINING}

Three ore-washery sedimentation basins in Chvaletice (200 m a.s.1.), the result of former sulfide mine tailings, are located at the border between two orographic and phytogeographic districts, the Železné hory Hills and the Elbe River lowlands (Czech Republic). Map coordinates of the sedimentation basins are $50^{\circ} 2^{\prime} 5 \mathrm{~N}$ latitude and $15^{\circ} 3^{\prime} \mathrm{E}$ longitude. The Elbe river passes along the northern edge of the Železné hory Hills and the artificial hills with sedimentation basins sit on an alluvial bedrock. The area has a more or less continental macroclimate. Mean annual precipitation moves in range from 500 to $600 \mathrm{~mm}$. Average monthly temperature is $9,5^{\circ} \mathrm{C}$ (relatively low precipitation levels and high mean temperatures, which is even more pronounced by low wood cover of the landscape). The extent of both daily and night temperatures is remarkable, similar to the extent of winter and summer temperatures, especially on such anthropogenic relief elements as abandoned sedimentation basins (Kováŕ, 2004).

A surface mine was open in 1952 and the sludge was mixed with water and transported a distance of from 500 to $2000 \mathrm{~m}$ into isolated areas of large-scale sedimentation basins with an overall area of 113 ha. The area of the first and oldest basin is 40 ha and its capacity was $12000000 \mathrm{~m}^{3}$, the area of the second sedimentation basin is 36 ha and its capacity was also $12000000 \mathrm{~m}^{3}$. The third and the youngest basin whose planned capacity has never been achieved and which remained drained and unreclaimed since the first half of the 1980s, became the main experimental object monitored and tested for spontaneous processes of biological colonization of the deposited substrate. The water column of the shallow standing water in the surface basin changed only slightly. The originally extremely low $\mathrm{pH}$ (around 3 units) increased due to secondary gypsum enrichments of the surface layers to 5.5-8.4 units. The dominant tree species are pioneer trees like birch (Betula pendula) and common aspen (Populus tremula), each of them with a different dispersal strategy. Birch spreads generative with small, anemochory seeds, while aspen is capable of clonal growth (but it is also possible to spread generatively). Accordingly, they are also able to respond to different stresses and disturbances connected with gypseous soils (Rauch, 2004), or fire (Štefánek, 2004). 
Fig. 1: Interior part of the former sedimentation basin of abandoned ore-washery deposit in Chvaletice with canopy of the tree stand dominated by birch Betula pendula and common aspen Populus tremula. (Photo Pavel Kovář)

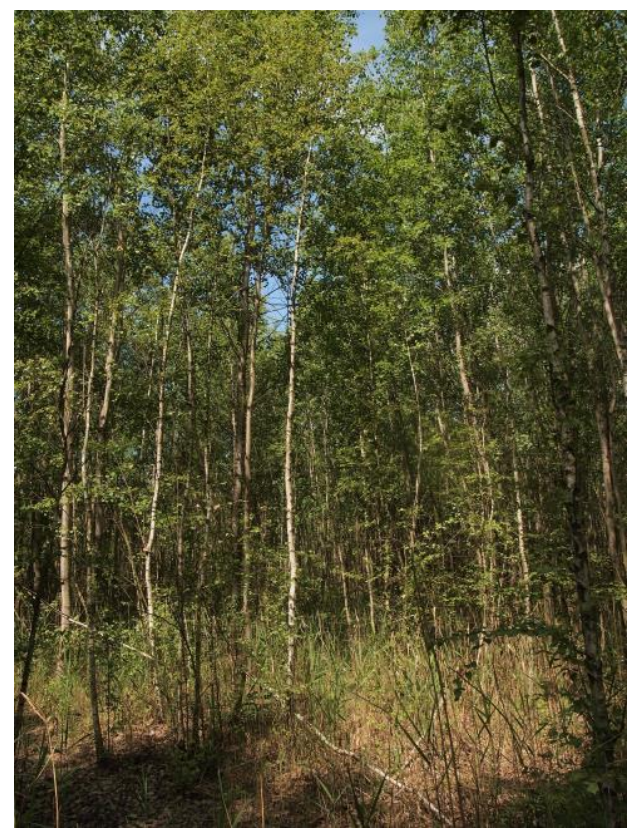

\section{SEEDLINGS OF WOODY PLANTS AND SURFACE SOIL CRUST}

At the start of revegetation of young (non-reclaimed) ore-washery deposit, considerable parts of the open sites in dried surface area were covered by a well developed moss and lichen layer; besides, salt incrustations covered some sites, corresponding with water sources and structure of deposits in the ground (Kovář, 1999). Acid substrate with a high amount of polymetalic sulphides and chemical intoxication of biomass (fungi, lichens, mosess, herb and woody plants) are analytically described (Kováŕ, 2004) by the following way, in short: sulphide-bearing mine tailings play pivotal role in mineral dissolution, acidification, transformation and transport processes related to formation of hardpan layer. Formation of gypsum and amorphous ferric oxyhydroxide precipitation has been documented for wide range of geochemical conditions of mine tailings (Grupner et al., 2007; Moncur et al., 2005). High salinity levels of the surface during dry periods, the uptake of microelements (mostly from the Fe-group of metals) are supported by a low $\mathrm{pH}$ with seasonal dynamics influenced by precipitation. Salinity represents one of serious contributions to the extreme conditions and is one of the key factors of species selection limiting seed bank viability. Such extreme conditions at the surface biofilm (composed of cryptogams, Neustupa et al., 2009) is combined with very high temperatures at the level of soil surface soil measured during culmination period of hot summer - around $60{ }^{\circ} \mathrm{C}$ (Hroudová et Zákravský, 2004). Diurnal courses of air humidity and evaporation rate in the summer measurement were typical of a day with strong sun radiation and evaporation, and of a night with irradiation and vapour condensation. Humidity fluctuations are moderated by moss layer: the carpet of the lichen Cladonia conoiocraea and $C$. nemoxyna species is fragmented, due to the summer temperature and moisture extremes, into irregular patches with elevated margins under which 
seeds of higher plants may be deposited. Such a microenvironment with crevices is colonized by ant species (Formica rufibarbis, Lasius niger, Tetramorium caespitum) which may potentially act as seed distributors (Jarešová et Kovár., 2004). It is interesting that myrmecochory acts in ambiguous directions: seeds of herbs are mostly transported into the ant-hill and its close surroundings, and seeds of woody plants are removed into suitable distance from the nest mound (Kovár et al., 2013). Dispersal activity of ants and the consequent establisment of tree seedlings are strong complementary mechanism and the key process of natural revegetation: Both actors in this complementarity are worthy to be named eco-engineers in given context (restored landscape). All the moisture and temperature dynamics of the crust imply its morphological (reversible) change from coherent to fragmented surface supporting seedling establisment. Seedlings are generally considered to be more sensitive to any kind of stress than adult plants, including the seedlings of trees (summer droughts and overheating cause extinction of most of the woody plant seedlings). The injury was observed when soil temperatures exceeded $46{ }^{\circ} \mathrm{C}$ - tree seedlings appeared but disappeared late. The measurements in plots lasting 13 years with annualy repeated records and assessed by spatial autocorrelation, shown that seedlings of woody species (B. pendula, P. tremula, Salix sp. div., occasionally Populus alba, P. nigra or Pinus sylvestris) may even die under the stress (Kovár et Herben, 2004). However, young trees going through the environmental filter finally survived and based directions of the consequent primary succession in spite of temporary retrogradation (Kovár, 2004). This is the first significant aspect of trees as the ecosystem engineers.

Fig. 2: Woody stands developed at the edge of the ore-washery deposit in Chvaletice during last 40 years are suppressed by new open places caused by chemical substrate changes in the soil profile. (Photo Pavel Kováŕ)

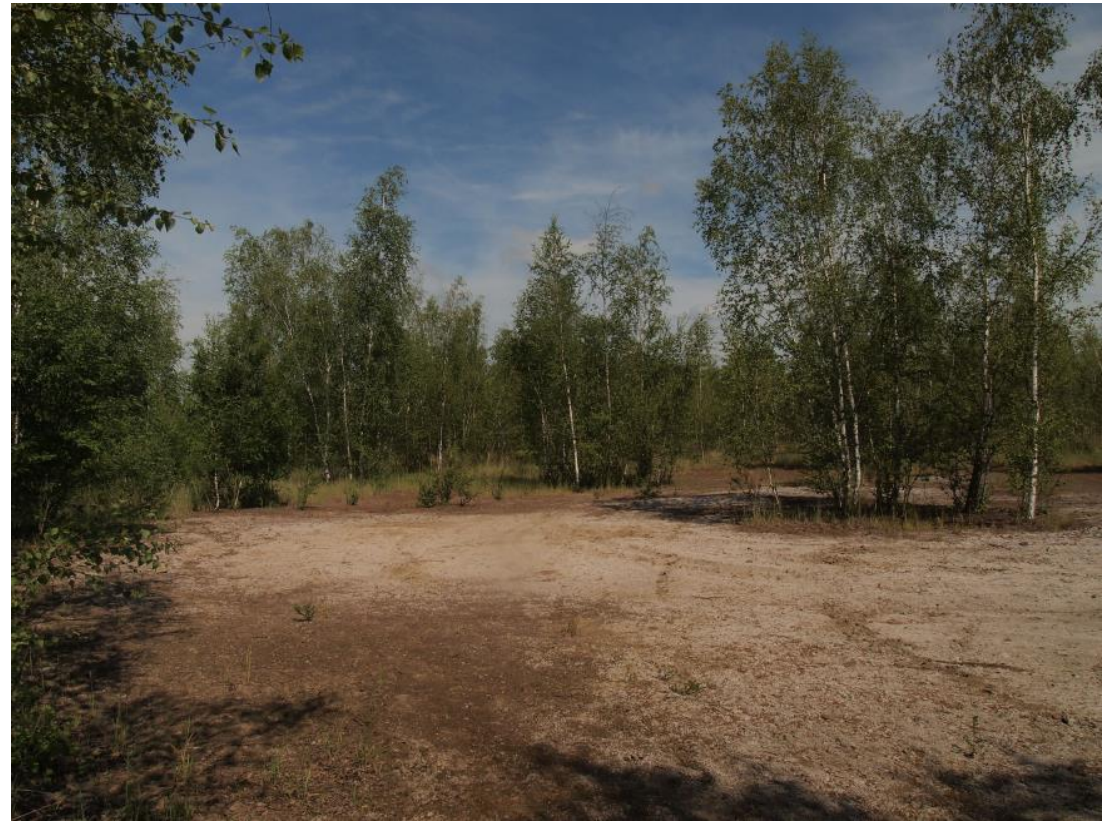




\section{FACILITATION AND INHIBITION FACTORS OF TREE CANOPY FORMATION}

The spatio-temporal model focused on vegetation propagation across a disturbed space linked to GIS was developed in our ore-washery deposit, Chvaletice (in comparison with another locality, Opatovice in Eastern Bohemia, with the ash-sludge deposit) to predict the vegetation density (Matějíček et Kovář, 2015). The image datasets based on network of cells (5 x 5 meters) of particular grid system in the frame of decades of years illustrates development of vegetation mosaic composed of quite open patches, those with herb layer, shrub layer and tree layer ones. There is an increase in the number of cells classified as high-density vegetation to the detriment of the cells classified as low-density vegetation. Well known is a facilitating influence of the shrub canopy on recruitment of tree seedlings (nurse plant effect, Kozlov et Zvereva, 2007; Gómez-Aparicio, 2009; Rejžek et al. 2016). Apparent coincidence of tree stands with mesophile conditions in the soil moisture is along the terrain gradient from edges of the deposit to the former central sedimentation depression. Edges are susceptible to create firm layers of gypsum in various depths under the substrate surface (several tens of centimeters) which represents an unconquerable barrier for the roots of trees and determines high limits of water permeability into bottom horizons. It is also the cause of rapid chemical changes in overlying substrate profile (desalinization, renewal of acidification, secondary accumulation of Fe-, $\mathrm{Mn}$ - and Al-oxides) which requires adaptive traits of plants (e.g., Escudero et al., 2015). All this implies extinction of relative mature tree individuals (mainly birches) after approx 4 decades of their growth at the edge of sedimentation body. Vital properties on the re-open unfavourable surface areas can be induced by mulching with addition of dry plant biomass (Štefánek et al., 2012) or by the artificial microbial inoculations (using mycorhiza effect, Vosátka et al., 1999). At the oposite end of the moisture gradient within the former sedimentation basin is periodically flooded (mainly in spring, by snow and rain precipitation) central depression with the absence of woody plants dominated by reed (Phragmites australis). It is another example of the blocked succession where rare seedlings of wilows (Salix alba, S. fragilis, S. triandra, S. purpurea, S. caprea) exhibit poor life turnover. Here, within the moist line of vegetation succession, the analogy with natural conditions (Maděra et Kovářová 2004; Maděra et al., 2009) apparently has significant limitations. Above mentioned cases of the tree prosperity, both successful growth (in moderate environmental conditions) and collapse/thinning after long-term changes in substrate profile (in extreme environmental conditions) exhibit high impacts on biodiversity of corresponding habitats - positive in the first case, negative in the second one. This means another significant aspect of trees as the ecosystem engineers. 
Prausová R., Štefánek M., Rauch O., Kovář P.: Trees as ecosystem engineers driving vegetational restoration/retrogradation of industrial deposits in cultural landscape

Fig. 3: Individuals of birch (Betula pendula) recently died at the edge of deposit in Chvaletice - distortion of their root system after collision with the gypsum hardpan layer originated in various depths under the substrate surface. (Photo Pavel Kovář)

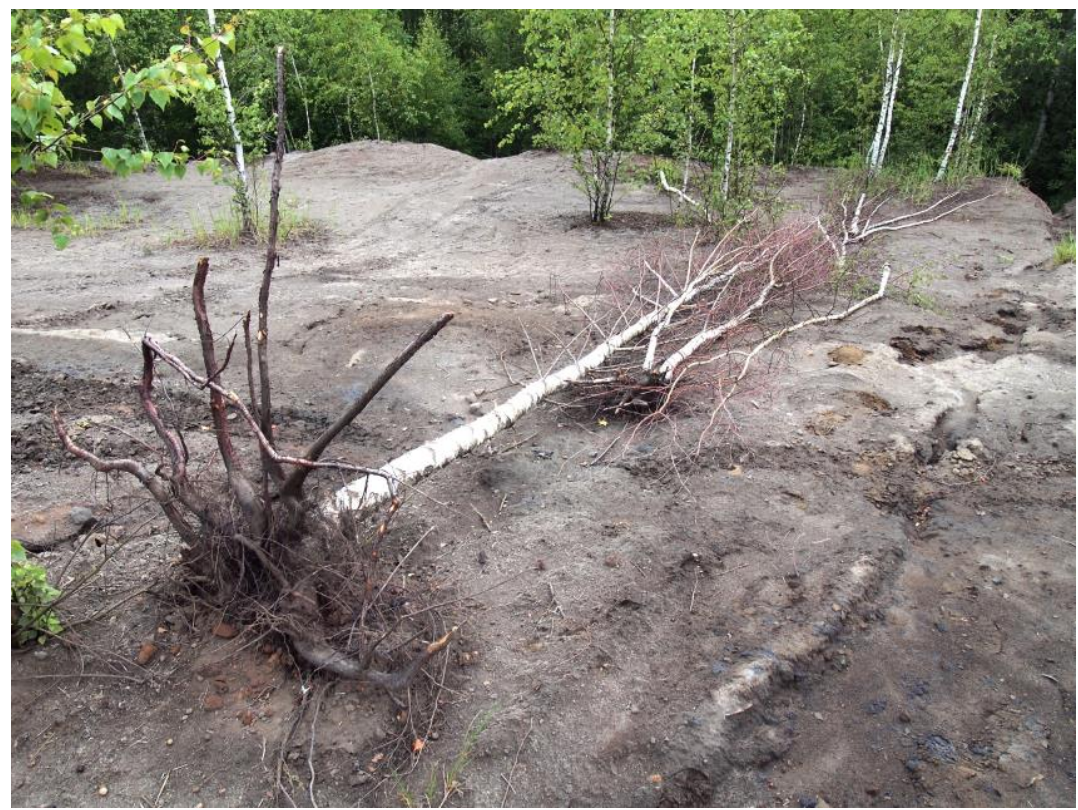

Fig. 4: Self-thinning of the young woody stand at the ecotone along bottom of the former sedimentation basin of the ore-washery in Chvaletice (the center of the basin, periodically and transiently flooded in spring, is overgrown with only reed Phragmites australis). (Photo Pavel Kovář)

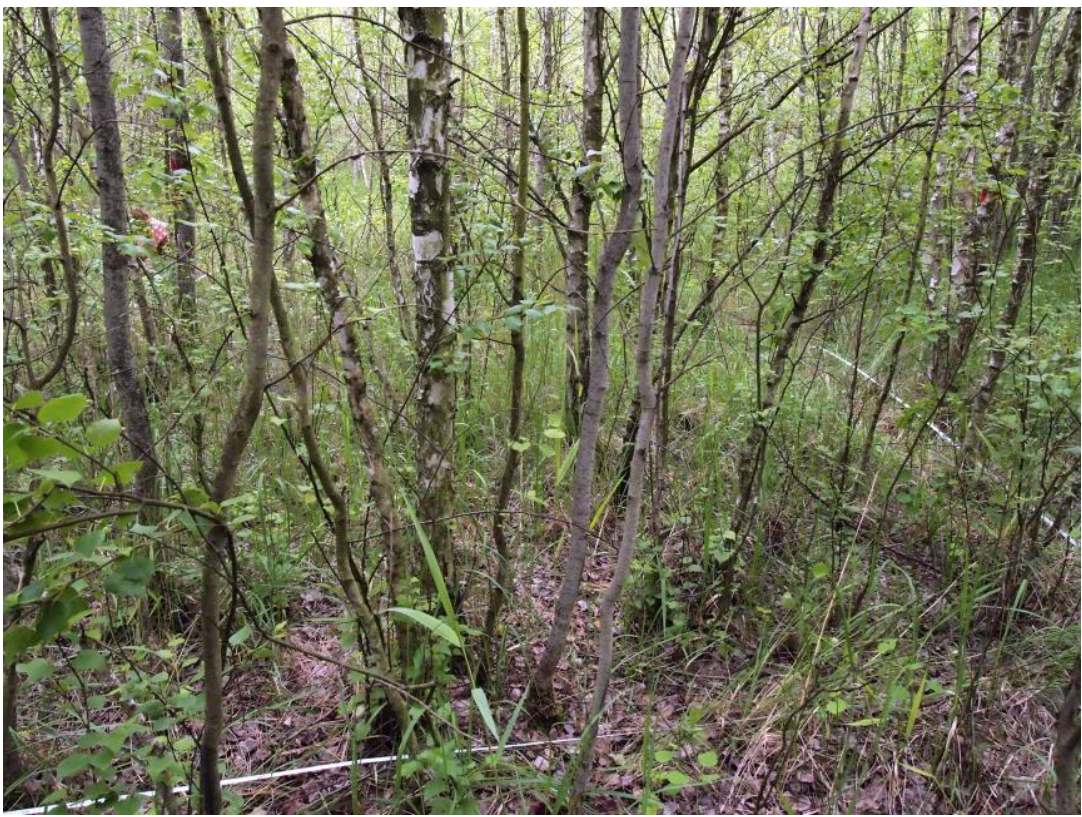




\section{TREE DOMINANTS AND VEGETATION SUCCESSION}

The most common plants dominants including trees were listed according to stages of vegetational succession across wider spectrum of antropogenous (industrial) habitats - with the highest frequency of birch (Betula pendula, rarely Betula pubescens), goat willow (Salix caprea), elderberry (Sambucus nigra), Scotch pine (Pinus sylvestris) and others (Prach et al., 2008). More detailed view with concentration to abandoned tailing containments with special emphasis to the locality of ore waste deposit in Chvaletice was published by Štefánek (2015). Ecological function of the all woody plants here, in close proximity to the power station in Chvaletice as the source of air pollution and heavy fallout may be analogical as in urban space - purification of the atmosphere (Brabec et al., 1981). Effect upon leaf litter of these tree species is inconsiderable, and it appears that leaf litter decay of both species occurs approximately at the same rate (Štefánek, 2004). In general, slow decomposition of litter may be one of problems for vegetation recovery (e.g., Kozlov et Zvereva, 2007), however, with the help of many organisms acting in detritus food chain, the leaf litter from established pioneer trees means a significant source of the shift in succession. Also bioturbation reversal of the soil layers with the accompanying enrichment with humus compounds (e.g. by ants, mainly those species of the advanced stages of succession constructing aboveground hill nests) - means the substantial factor of the ecosystem progress (Kovár et al., 2013). So, this sequence of tree species during course of time (Mrázek, 2004; Kováŕ et al., 2011) acts step by step, with direct or indirect impacts and under the interactive relationships in favor of complexity of life in newly balanced ecosystem: trees as ecosystem engineers function in temporal cascades.

\section{CONCLUSIONS}

Trees colonizing post-industrial sites, mainly deposits of ore-washery wastes organized into tailings containments can serve as ecosystem engineers:

- they are natural tools functioning in regulating aspects (moderation of microclimate stress, enhancement of the substrate quality, purification role in relation to atmospheric pollution),

- they provide habitat to a variety of biological species which is critical for increasing biodiversity as well as in conditions of unfavourable substrate changes they function in the opposite direction (decreasing biodiversity),

- they govern succession of complex vegetation in different trajectories including backward development (retrogradation) under extreme transformation processes in the soil environment (vegetational degradation).

\section{ACKNOWLEDGEMENTS}

These results were supported by the Fund for the Development of Universities of the Czech Ministry of Education, Grant No. 2348, the research project MSM 31300042 "Ecological plasticity and taxonomical variability of expansive plant species", of the Czech Ministry of Education and the institutional fund of the Faculty of Science, University of Hradec Králové (project SV no. 2116). 
Prausová R., Štefánek M., Rauch O., Kovář P.: Trees as ecosystem engineers driving vegetational restoration/retrogradation of industrial deposits in cultural landscape

\section{REFERENCES}

Brabec, E., Kovár̆, P. et Drábková, A. (1981). Particle deposition in three vegetation stands: a seasonal change. - Atmos. Environ., 15: 583-587.

Byers, J.E., Cuddington, K., Jones, C. G., Talley, T. S., Hastings, A., Lambrinos, J. G., Crooks, J. A. et Wilson, W. G. (2006). Using ecosystem engineers to restore ecological systems. - Trends in Ecology \& Evolution, 21(9): 493-500.

Escudero, A., Palacio, S., Maestre1, F. T. et Luzuriaga, A. L. (2015). Plant life on gypsum: a review of its multiple facets. - Biological Reviews, 90: 1-18.

Gómez-Aparicio, L. (2009). The role of plant interactions in the restoration of degraded ecosystems: a meta-analysis across life-forms and ecosystems. - Journal of Ecology, 97: $1202-1214$.

Graf, F. et Frei, M. (2013). Soil aggregate stability related to soil density, root length, and mycorrhiza using site-specific Alnus incana and Melanogaster variegatus s.1.. - Ecological Engineering, 57: 314-323.

Grupner, T., Kassahun, A., Rammlmair, D., Meima, J.A., Kock, D., Furche, M., Fiege, A., Schippers, A. et Melcher, F. (2007). Formation of sequences of cemented layers and hardpans within sulfide-bearing mine tailings (mine district Freiberg, Germany. - Applied Geochemistry, 22: 2486-2508.

Hastings, A., Byers, J.E., Crooks, J. A., Cuddington, K., Jones, C. G., Lambrinos, J. G., Talley, T. S. et Wilson, W. G. (2007). Ecosystem engineering in space and time. - Ecology Letters, (2007) 10: 153-164.

Hroudová, Z. et Zákravský, P. (2004). The influence of the moss layer on soil surface microclimate in an abandoned ore-washery sedimentation basin. - In: Kovár P. (ed.): Natural Recovery of Human-Made Deposits in Landscape (Biotic Interactions and Ore/Ash-Slag Artificial Ecosystems) (pp. 235-247).- Academia, Prague.

Jarešová, I. et Kováŕ, P. (2004). Interactions between ants and plants during vegetation succession in the abandoned ore-washery sedimentation basin in Chvaletice. - In: Kovár P. (ed.): Natural Recovery of Human-Made Deposits in Landscape (Biotic Interactions and Ore/Ash-Slag Artificial Ecosystems) (pp. 300-310). - Academia, Prague.

Kováŕ, P. (1999). Biotic interactions and restoration ecology of abandoned sedimentation ponds of toxic materials. - In: Kovár P. (ed.): Nature and Culture in Landscape Ecology (Experiences for the 3rd Millennium), (pp. 290-302). The Karolinum Press, Prague.

Kováŕ, P. (2004). Industrial deposits of abandoned sedimentation basins - technology of the origin and vegetation. - In: Kovár P. (ed.): Natural Recovery of Human-Made Deposits in Landscape (Biotic Interactions and Ore/Ash-Slag Artificial Ecosystems) (pp. 15-29) Academia, Prague.

Kováŕ, P. et Herben, T. (2004). Small-scale spatiotemporal dynamics of plant cover during the initial phase of primary succession in an abandoned ore-washery sedimentation basin. In: Kováŕ P. (ed.): Natural Recovery of Human-Made Deposits in Landscape (Biotic Interactions and Ore/Ash-Slag Artificial Ecosystems) (pp. 277-284) - Academia, Prague.

Kovář, P., Štefánek, M. et Mrázek, J., (2011). Responses of vegetation stages with woody dominants to stress and disturbance during succession on abandoned tailings in cultural landscape. - Journal of Landscape Ecology, 4(2): 35-48.

Kovář, P., Vojtíšek, P. et Zentsová, I. (2013). Ants as ecosystem engineers in natural restoration of human made habitats. - Journal of Landscape Ecology, 6(1): 18-31. 
Kozlov, M. V. et Zvereva, E. I. (2007). Industrial barrens: extreme habitats created by non-ferrous metallurgy. - In: Amils R., Ellis-Evans C. et Hinghofer-Szalkay H. G. (eds.): Life in extreme environments. - Springer.

Maděra, P. et Kovářová, P. (2004). Primary succession of white willow communities in the supraregional biocorridor in the Middle water reservoir of Nové Mlýny. - Ekológia, 23, Suppl. 1/2004: 191-204.

Maděra, P., Svobodová, I. et Packová, P. (2009). Oecesis of White Willow Communities in the nature reserve Věstonická nádrž reservoir. - Ekológia, 28 (1): 7-21.

Matějíček, L. et Kovář, P. (2015). Computer Based Modeling of Vegetation Propagation across a Disturbed Space Linked to GIS. - Journal of Earth Science and Engineering 5 (2015): 410-416.

Moncur, M.C., Ptacek, C.J., Blowes, D.W. et Jambor, J.L. (2005). Release, transport and attenuation of metals from an old tailings impoundment. - Applied Geochemistry, 20: 639659.

Mrázek, J. (2004). Comparison of the growth of dominant trees (Betula pendula, Populus tremula) in primary succession on toxic substrate. - In: Kovár P. (ed.): Natural Recovery of Human-Made Deposits in Landscape (Biotic Interactions and Ore/Ash-Slag Artificial Ecosystems) (pp. 294-299) - Academia, Prague.

Neustupa, J., Škaloud, P., Peksa, O., Kubátová, A., Soldán, Z, Černá, K., Prášil, K., Bukovská, P., Vojta, J., Pažoutová, M., Veselá, J. et Škaloudová, M. (2009). The biological soil crusts in Central European ecosystems, with special reference to taxonomic structure and ecology of the surface crusts at Czech ore-waste and ash-slag sedimentation industrial basins. - Novitates Botanicae Universitatis Carolinae, 19/2008: 9-99.

Paz-Kagan, T., Zaady, E., Shachak, M. et Karnieli, A. (2016). Transformation of shrublands to forests: The role of woody species as ecosystem engineers and landscape modulators. Forest Ecology and Management, 361: 257-268.

Prach, K., Bastl, M., Konvalinková, P., Kováŕ, P., Novák, J., Pyšek, P., Řehounková, K. et Sádlo, J. (2008). Vegetation succession in human-made habitats in the Czech Republic survey of dominant species and stages - Př́roda, Praha, 26: 5-26 [in Czech]

Prach, K., Tichý, L., Lencová, K., Adámek, M., Koutecký, T., Sádlo, J., Bartošová, A., Novák, J., Kovář, P., Šmilauer, P. et Řehounková, K. (2016). Does succession run towards potential naturalvegetation? An analysis across seres. - Journal of Vegetation Science, 27: 515-523.

Rauch, O. (2004). Genesis and characteristics of orewaste sulphate soils at Chvaletice. - In: Kováŕ P. (ed.): Natural Recovery of Human-Made Deposits in Landscape (Biotic Interactions and Ore/Ash-Slag Artificial Ecosystems) (pp. 45-58) - Academia, Prague.

Rebele, F. et Lehmann, C. (2016). Twenty years of woodland establishment through natural succession on a sandy landfillsite in Berlin, Germany. - Urban Forestry \& Urban Greening, 18: 182-189.

Rejžek, M., Svátek, M., Šebesta, J., Adolt, R., Maděra, P. et Matula, R. (2016). Loss of a single tree species will lead to an overal decline in plant diversity: Effect of Dracaena cinnabari Balf. F. on the vegetation of Socotra Island. - Biological Conservation, 196: 165-172.

Štefánek, M. (2004). Secondary succession after fire on an abandoned ore-washery sedimentation basin - different trajectories (A comparison with primary succession). - In: Kovář P. (ed.): Natural Recovery of Human-Made Deposits in Landscape (Biotic 
Interactions and Ore/Ash-Slag Artificial Ecosystems) (pp. 248-266) - Academia, Prague.

Štefánek, M. (2015). Role of plant dominants on abandoned tailings containment from manganese-ore mining in Chvaletice, Eastern Bohemia, Czech Republic, (Overview of long-term case studies). - Journal of Landscape Ecology, 8(3): 92-97.

Štefánek, M., Kovář, P. et Dlouhá, V. (2012). Role of fire episode, leaf litter decomposition and mulching effects in restoration of surface soil crust microecosystem on abandoned tailings containment. - Journal of Landscape Ecology, 5(3): 57-69.

Urbanová, J., Kovář, P. et Dostál, P. (2017). What processes shape early-successional vegetation in fly ash and mine tailings? - Plant Ecology, 218(2): 127-137.

Vaňková, J. et Kovář, P. (2004). Plant species diversity in the biotopes of un-reclaimed industrial deposits as artificial islands in landscape. - In: Kovár P. (ed.): Natural Recovery of Human-Made Deposits in Landscape (Biotic Interactions and Ore/Ash-Slag Artificial Ecosystems) (pp. 30-45) - Academia, Prague.

Vosátka, M., Rydlová, J. et Malcová, R. (1999). Microbial inoculations of plants for revegetation of disturbed soils in degraded ecosystems. - In: Kovár P. (ed.): Nature and culture in landscape ecology (Experiences for the 3rd Millennium) (pp. 303-317), The Karolinum Press, Prague. 